\title{
BADANIA POZNAŃSKICH ARCHEOLOGÓW NAD OSADNICTWEM OBRONNYM EPOKI BRĄZU
}

\author{
INVESTIGATIONS OF BRONZE AGE FORTIFIED \\ SETTLEMENTS BY ARCHAEOLOGISTS FROM POZNAŃ
}

\author{
Mateusz Jaeger \\ Instytut Kultury Europejskiej, Uniwersytet im. Adama Mickiewicza w Poznaniu \\ ul. Kostrzewskiego 5-7, 62-200 Gniezno, Poland
}

ABSTRACT. The text discusses the most important research programs devoted to the Bronze Age defensive settlement, initiated by archaeologists from the Adam Mickiewicz University in Poznan.

\section{KILKA UWAG WSTĘPNYCH}

Osadnictwo obronne stanowi charakterystyczną cechę europejskiej epoki brązu. Stanowiska mające sztuczne umocnienia, w pierwszej połowie II tysiąclecia przed Chr. występowały w większości regionów Europy Środkowej ${ }^{1}$. Badania tego typu obiektów wyraźnie rozwinęły się w środowisku poznańskiej archeologii w ostatnich dwóch dekadach.

Znaczące rozmiary osad obronnych oraz liczba źródeł ruchomych i nieruchomych, powodują, że ich badanie stanowi nie lada wyzwanie organizacyjne, logistyczne i wreszcie również finansowe. Podnoszone systematycznie standardy pracy naukowej prahistoryków, zmierzające ku coraz bardziej intensywnej współpracy archeologii z innymi dziedzinami nauki, dodatkowo komplikują realizację projektów poświęconych ufortyfikowanym osiedlom. Ze względu na powyższe czynniki niezbędne jest formowanie programów badawczych, których realizacja jest finansowana ze środków zewnętrznych, tj. niezwiązanych z ogólnym budżetem poszczególnych jednostek naukowych. Waga problematyki osadnictwa obronnego dla rozważań nad europejską epoką brązu pozwala ponadto na budowanie niezbędnych

\footnotetext{
${ }^{1}$ Jaeger 2011.
} 
„naukowych sojuszy” - zespołów interdyscyplinarnych oraz międzynarodowych. Projekty realizowane w tak zarysowanych ramach mają znaczne możliwości organizacyjne i analityczne, z wykorzystaniem zaplecza poszczególnych instytucji partnerskich.

Omawiane w niniejszym artykule programy badawcze stanowią rezultat przyjęcia przez archeologów poznańskich opisanej strategii, zarówno w odniesieniu do stanowisk na terenie Polski, jak i za granicą - na Węgrzech ${ }^{2}$.

\section{BADANIA ARCHEOLOGICZNE OSADNICTWA OBRONNEGO EPOKI BRĄZU W POLSCE}

Sztandarowym projektem realizowanym w omawianym zakresie jest interdyscyplinarny program badań archeologicznych poświęcony osadzie kultury unietyckiej w Bruszczewie ${ }^{3}$. Stanowisko o bogatej i długiej historii badań, której najważniejszymi etapami są prace prowadzone przez pracowników Muzeum Archeologicznego w Poznaniu (lata 60. XX w.; pod kierownictwem Z. Pieczyńskiego), powtórne rozpoznanie stanowiska przez archeologów z Instytutu Prahistorii Uniwersytetu im. Adama Mickiewicza w Poznaniu (lata 90. XX w.; pod kierownictwem J. Czebreszu$\mathrm{ka}$ ) oraz kontynuacja prac w ramach polsko-niemieckiego projektu, rozpoczętego w 1999 r. (współpraca między IP UAM oraz uniwersytetami niemieckimi: początkowo w Berlinie, następnie w Bambergu, a ostatecznie w Kilonii; pod kierownictwem J. Czebreszuka i J. Müllera) ${ }^{4}$. W ramach interdyscyplinarnego programu badawczego, realizowanego w latach 1999-2008, udało się zgromadzić informacje na temat najistotniejszych aspektów funkcjonowania osady. Badania wykopaliskowe, zaprojektowane na bazie prospekcji magnetometrycznej ${ }^{5}$, pozwoliły rozpoznać formę oraz rozmiary umocnień otaczających osadę, a także pozostałości zabudowy jej wnętrza (ryc. 1).

Wykonane na obszarze półwyspu bruszczewskiego sondaże i odwierty przyniosły ważną informację o istnieniu warstw torfu w jego otoczeniu. Specyficzne, beztlenowe warunki, stanowiące pozostałość po pierwotnie oblewającym półwysep jeziorze, doskonale zakonserwowały drewniane umocnienia, pozostałości zabudowy w strefie brzegowej oraz unikalny w swej formie pochówek.

\footnotetext{
${ }^{2}$ Projekty finansowane z grantów Ministerstwa Nauki i Szkolnictwa Wyższego: nr 1H01H02728 (Bruszczewo, Pudliszki/Polska), nr N N109 053539 (Bruszczewo/Polska); Narodowego Centrum Nauki: nr 2012/05/B/HS3/03714 (Kakucs/Węgry), oraz The Wenner Gren Foundation (USA) nr: ICRG-109 (dolina Benty/Węgry).

${ }^{3}$ Czebreszuk, Müller 2004a; Müller, Czebreszuk, Kneisel 2010.

${ }^{4}$ Czebreszuk, Müller, Silska 2004; Müller, Czebreszuk, Kneisel 2010.

${ }^{5}$ Ducke, Müller 2004.
} 


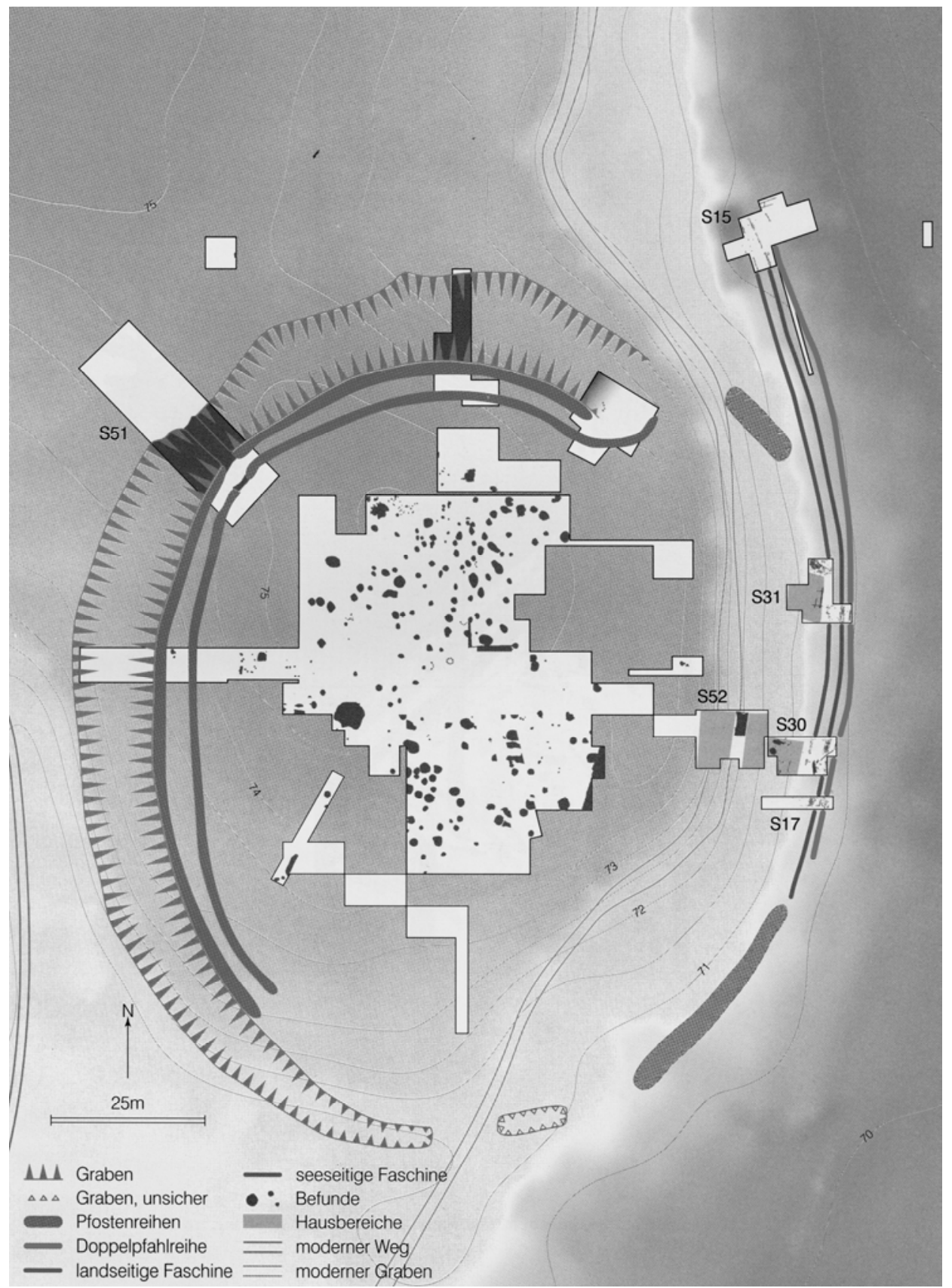

Ryc. 1. Bruszczewo. Ogólny plan stanowiska z planem wykopów oraz rekonstrukcją przebiegu umocnień (za: Kneisel et al. 2008)

Fig. 1. Bruszczewo. General plan of the site with trenches and a reconstruction of defensive structure (after Kneisel et al. 2008) 
Stan zachowania fortyfikacji pozwolił precyzyjnie odtworzyć ich pierwotny przebieg oraz formę i rozmiary. Umocnienia w rozpoznanej wykopaliskowo części osady stanowiła masywna ściana wzniesiona $\mathrm{z}$ przepołowionych pali wsuwanych pomiędzy podwójne słupy oraz dwa rzędy konstrukcji faszynowych ${ }^{6}$ (ryc. 2). Pozostałości budynków, zlokalizowane bliżej strefy mineralnej stanowiska, zachowały się znacznie gorzej. Mimo to możliwe było zadokumentowanie wielu istotnych elementów konstrukcyjnych budynków z wczesnej epoki brązu?

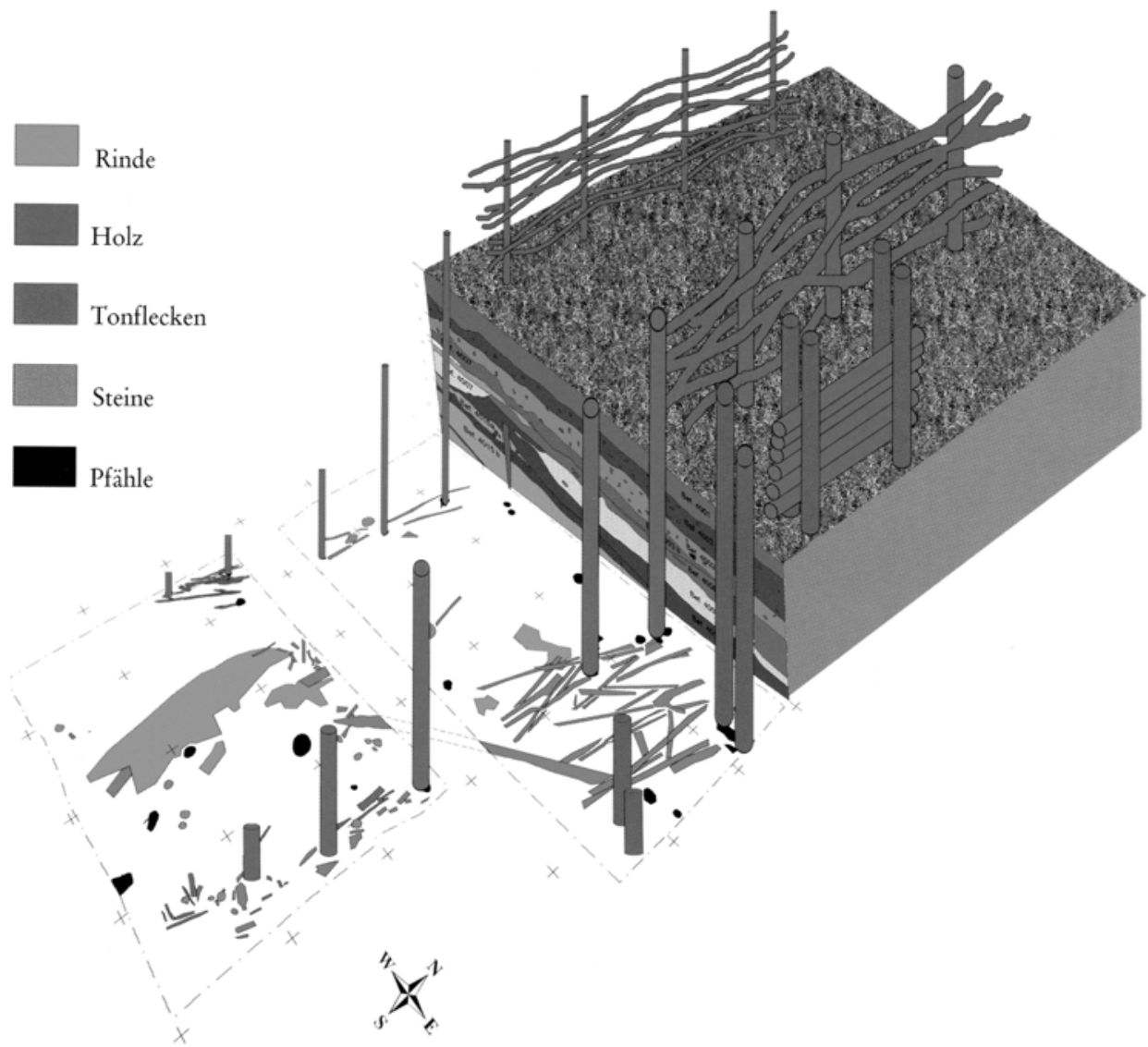

Ryc. 2. Bruszczewo. Wizualizacja trzech linii umocnień w strefie torfowej stanowiska (za: Kneisel et al. 2008)

Fig. 2. Bruszczewo. Visualisation of three lines of defensive structures in a peaty part of the site (after Kneisel et al. 2008)

${ }^{6}$ Müller 2004, 125-133.

${ }^{7}$ Kneisel 2010a. 
Jedyny grób, który odkryto do tej pory w Bruszczewie, krył szczątki młodego mężczyzny. Jego ciało złożono w wiklinowej macie ${ }^{8}$.

Badania prowadzone $\mathrm{w}$ strefie torfowej osady zaowocowały jednak nie tylko odkryciem wspomnianych obiektów nieruchomych, ale dostarczyły także wielu znalezisk wykonanych z materiałów organicznych (drewno, kość, poroże), które zazwyczaj nie zachowują się w warunkach glebowych stanowisk archeologicznych Środkowej Europy9.

Z powodu wciąż trwającej rolniczej eksploatacji obszaru stanowiska utracone zostały bezpowrotnie istotne źródła dotyczące zabudowy wewnętrznej osady w strefie mineralnej. W trakcie wielu sezonów wykopaliskowych zadokumentowano jednak znaczną liczby dołków posłupowych, jam gospodarczych oraz strefę warstwy kulturowej z wczesnej epoki brązu ${ }^{10}$. Mimo braku możliwości precyzyjnego odtworzenia struktury zabudowy wnętrza osady, liczba obiektów nieruchomych jednoznacznie wskazuje na intensywność oraz długotrwałość procesu osadniczego w Bruszczewie (ryc. 1).

Zdecydowanie bardziej czytelne były pozostałości umocnień w strefie mineralnej półwyspu - fosy oraz dwóch linii palisad. Fosa miała znaczne rozmiary. Jej szerokość sięgała $20 \mathrm{~m}$, a głębokość $4 \mathrm{~m}$. Palisady tworzyły rzędy masywnych dębowych słupów. Częściowo posadowiono je w wodzie pierwotnie wypełniającej fosę ${ }^{11}$ (ryc. 3).

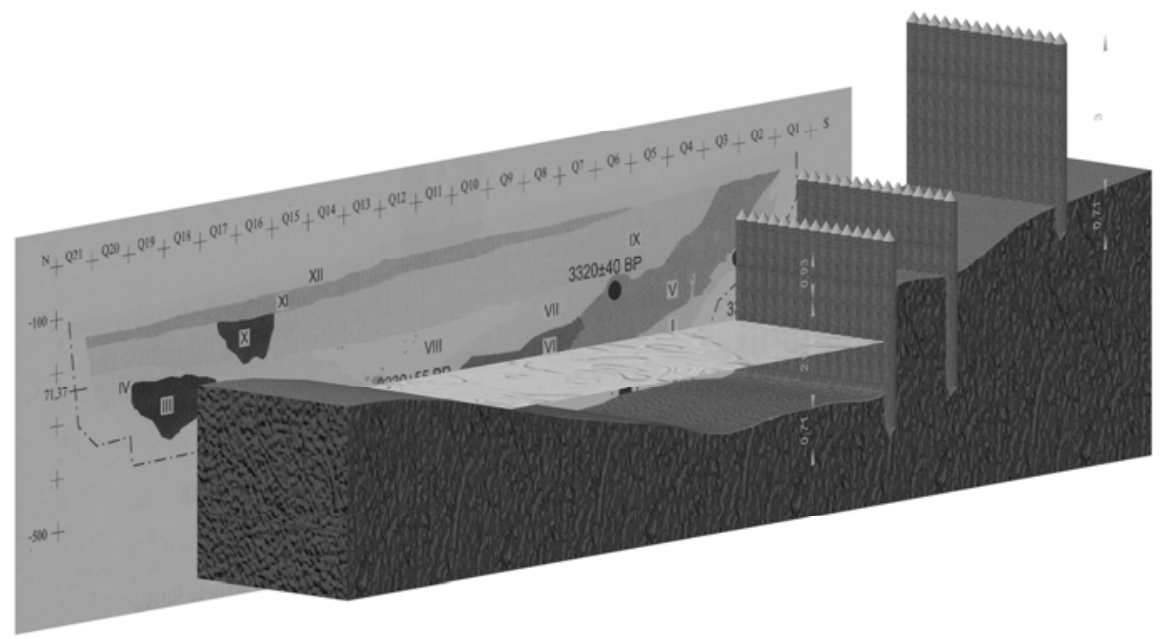

Ryc. 3. Bruszczewo. Wizualizacja trzech linii umocnień w strefie mineralnej stanowiska (za Stróżyk 2011)

Fig. 3. Bruszczewo. Visualisation of three lines of defensive structures in a mineral part of the site (after Stróżyk 2011)

\footnotetext{
${ }^{8}$ Kneisel 2010b; Jaeger 2012.

${ }^{9}$ Kneisel 2010c; Kneisel, Kroll 2010.

${ }^{10}$ Czebreszuk, Suchowska 2010.

${ }^{11}$ Müller, Czebreszuk 2003, 465, Abb.10; Czebreszuk, Ducke, Müller, Silska 2004, 71.
} 
Zarówno w strefie mineralnej, jak i torfowej stanowiska odkryto liczne zabytki jednoznacznie poświadczające lokalną produkcję metalurgiczną. Oprócz przedmiotów gotowych badania ujawniły wytwory nieukończone, wytopki metalu oraz zbiór narzędzi metalurgicznych: tygiel, łyżkę odlewniczą, końcówki dysz miechów oraz piaskowcową formę do odlewania masywnych bransolet. Badania metalograficzne dowiodły wczesnej metryki produkcji brązu w Bruszczewie oraz długotrwałość tego zjawiska, prawdopodobnie obejmującego cały okres istnienia osady ${ }^{12}$ i będącego jednym z głównych powodów prosperity lokalnej społeczności ${ }^{13}$. Równie istotnym, choć niepozornym, znaleziskiem jest bursztynowy paciorek ${ }^{14}$. Pozwala on hipotetycznie interpretować Bruszczewo jako jeden z elementów skomplikowanej sieci wymiany sukcynitu pomiędzy wybrzeżem Bałtyku a odbiorcami z południa Europy ${ }^{15}$.

Mimo pozyskania kilkudziesięciu dat radiowęglowych oraz stworzenia lokalnej krzywej dendrologicznej wciąż nie zamknięto dyskusji na temat chronologii stanowiska. Jej uszczegółowienie odbywa się systematycznie wraz z przyrostem danych. $\mathrm{W}$ świetle dostępnych informacji okres funkcjonowania osady mieścił się pomiędzy XIX i XVII stuleciem przed Chr. ${ }^{16}$. Projekt bruszczewski to w istocie rozbudowany program badań interdyscyplinarnych. Analizy tafonomiczne i archeozoologiczne dały wgląd $\mathrm{w}$ strukturę hodowli i gospodarkę zwierzętami ${ }^{17}$. Badania makroszczątków i profili palinologicznych pozwoliły z kolei na rekonstrukcję pierwotnego środowiska naturalnego i sposobów oraz skali jego eksploatacji ${ }^{18}$. Dzięki szczegółowym analizom zespołu specjalistów z zakresu różnych dziedzin nauki udało się określić potencjalne czynniki związane z zanikiem osady: znaczną deforestację oraz degradację środowiska naturalnego, $\mathrm{z}$ wodą pobliskiego jeziora włącznie. Swoista katastrofa ekologiczna, spowodowana intensywną gospodarką rolno-hodowlaną prowadzoną przez mieszkańców osady, wraz z obserwowanym w Europie kryzysem określonego modelu kultury i społeczeństwa stworzyły splot okoliczności, które doprowadziły osadę w Bruszczewie do upadku.

W ramach projektu bruszczewskiego podjęto również zadanie weryfikacji tez sugerujących istnienie na obszarze Wielkopolski sieci wczesnobrązowych osad obronnych. Jednym z obiektów, któremu przypisywano podobną do Bruszczewa chronologię i funkcję, jest stanowisko nr 5 w Pudliszkach ${ }^{19}$. W 2005 r. przeprowadzono na jego obszarze prospekcję magnetometryczną oraz wykonano cyfrowy model terenu. Ujawniły one bardziej skomplikowaną strukturę i rozmiary osady.

\footnotetext{
${ }^{12}$ Rassmann 2004; 2010.

${ }^{13}$ Jaeger, Czebreszuk 2010; Jaeger 2012.

${ }^{14}$ Czebreszuk, Kneisel, Müller 2010.

${ }^{15}$ Jaeger 2010a; Czebreszuk 2011.

${ }^{16}$ Heußner, Ważny 2010.

${ }^{17}$ Makowiecki 2004; Makowiecki, Drejer 2010; Marciniak 2010.

${ }^{18}$ Haas, Wahlmüller 2010.

${ }^{19}$ Gediga 1983; Kłosińska 1997, 104; Czebreszuk, Müller 2004b, 43, Abb. 16.
} 
Wykorzystując doświadczenie z badań Bruszczewa, badania sondażowe zaplanowano na podstawie wyników prospekcji magnetometrycznej. Mimo intensywnej współczesnej eksploatacji terenu stanowiska badania nieinwazyjne ujawniły stosunkowo dobrze zachowane kamienno-drewniane fortyfikacje. Analiza pozyskanych prób radiowęglowych pozwoliła jednoznacznie zweryfikować pogląd o chronologii umocnień w Pudliszkach, których powstanie należy wiązać z późnym odcinkiem epoki brązu i kulturą łużycką ${ }^{20}$.

\section{BADANIA ARCHEOLOGICZNE OSADNICTWA OBRONNEGO EPOKI BRĄZU NA WEGGRECH}

W 1. połowie II tysiąclecia przed Chr. obszary dzisiejszych Węgier stały się areną intensywnego rozwoju osadnictwa obronnego, związanego przede wszystkim z ugrupowaniami kulturowymi Vatya oraz Otomani-Füzesabony ${ }^{21}$. Wiele stanowisk ma charakter wielowarstwowy lub wręcz tellowy. Część z osad była nieprzerwanie użytkowana od schyłku wczesnej epoki brązu (w terminologii węgierskiej, przypadającego na koniec III tysiąclecia przed Chr.) po tzw. horyzont Koszider, tradycyjnie rozumiany jako koniec sekwencji rozwoju środkowobrązowych tzw. kultur tellowych Kotliny Karpackiej ${ }^{22}$.

W roku 2010 doszło do podpisania umowy o współpracy pomiędzy Uniwersytetem im. Adama Mickiewicza w Poznaniu a Instytutem Archeologii Węgierskiej Akademii Nauk w Budapeszcie. Na jej mocy w kwietniu tego samego roku wykonano badania magnetometryczne osady obronnej kultury Vatya w Kakucs-Turján ${ }^{23}$ (ryc. 4). Stanowisko to zidentyfikowane zostało na zdjęciach satelitarnych i stanowi jedną z pięciu osad obronnych zlokalizowanych w relatywnie niewielkim mikroregionie Kakucs (ok. 40 km na południowy wschód od Budapesztu ${ }^{24}$ ) (ryc. 5). Wspomniane badania nieinwazyjne ujawniły skomplikowaną strukturę osiedla. Podzielone jest ono umocnieniami na trzy części. Wyłącznie $w$ jednej $\mathrm{z}$ nich, dookolnie, wzdłuż linii fortyfikacji widoczne są pozostałości chat. Obraz dwóch pozostałych partii osady różni się charakterem i ilością zarejestrowanych anomalii magnetycznych. Na podstawie archiwalnych badań stanowisk o podobnej strukturze ostrożnie można przyjąć, że każda z części osady miała inną funkcję. Prawdopodobnie w jednej z nich kumulowała się różnoraka produkcja (liczne anomalie związane

\footnotetext{
${ }^{20}$ Jaeger, Czebreszuk, Müller 2008; Jaeger 2010b.

${ }^{21} \mathrm{~W}$ niniejszym opracowaniu używany jest przyjęty w polskiej prahistoriografii termin Otomani-Füzesabony, również na oznaczenie ugrupowań określanych przez badaczy węgierskich jako Ottomány-Gyulavarsánd oraz Füzesabony (Németi, Molnár 2012, 10-13).

${ }^{22}$ Bóna 1992; Jaeger 2010a, 173-174; 2011, 111, 112.

${ }^{23}$ Jaeger, Kulcsár, Pospieszny, Szeverenyi 2010.

${ }^{24}$ Kulcsár, Szeverenyi 2012; Jaeger, Kulcsár 2013.
} 


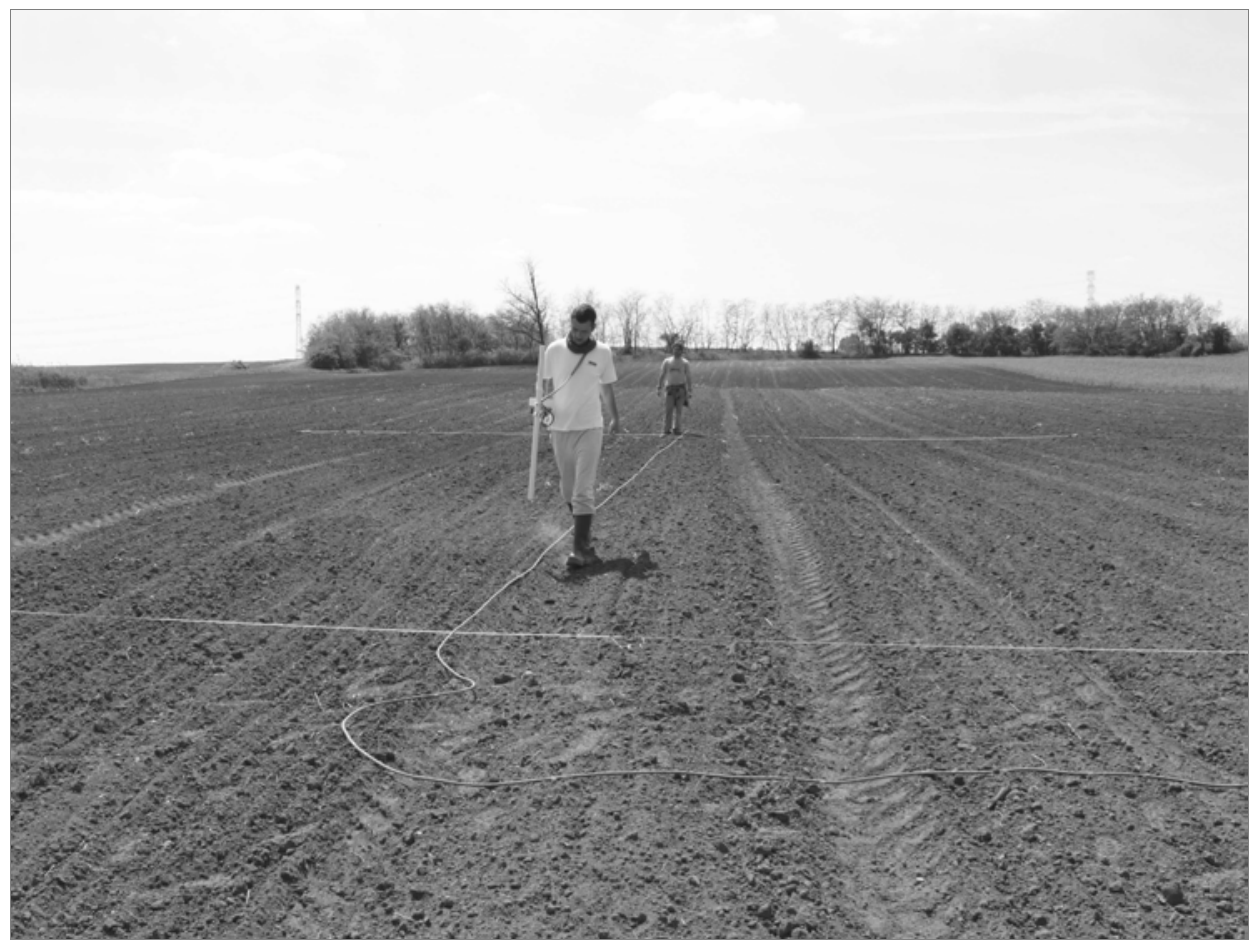

Ryc. 4. Kakucs-Turján. Prospekcja magnetometryczna stanowiska (fot. Ł. Pospieszny)

Fig. 4. Kakucs-Turján. Magnetometric prospection of the site (photo Ł. Pospieszny)

z obecnością jam gospodarczych). Natomiast w drugiej części osady koszarowano zwierzęta hodowlane (nieliczne anomalie związane z obecnością obiektów wziemnych; bliskość wody) ${ }^{25}$. Taki typ konstruowania przestrzeni osad obronnych kultury Vatya był postulowany w literaturze przedmiotu, jednakże dotąd nie został jednoznacznie potwierdzony ${ }^{26}$. Oprócz specyficznej struktury osady, badania magnetometryczne ujawniły również obecność kolistej struktury w obrębie linii umocnień. Dotychczas takie obiekty rejestrowano wyłącznie przy okazji tworzenia planów wysokościowych osad obronnych kultury Vatya. Ich funkcja nie jest jednoznacznie wyjaśniona. W tradycji archeologii węgierskiej obiekty te nazywa się „,bastionami" ${ }^{27}$, co sugeruje, że mamy do czynienia z elementami fortyfikacji.

Prospekcja magnetometryczna w Kakucs-Turján pozwoliła na precyzyjne udokumentowanie stanu zachowania osady. Pełna interpretacja uzyskanego obrazu nie była jednak możliwa ze względu na brak materiałów porównawczych. Mimo długiej

\footnotetext{
${ }^{25}$ Jaeger 2011, 85-87.

${ }^{26}$ Kovács 1982, 283.

${ }^{27}$ Horváth, Kozak, Petö 2001, 7.
} 


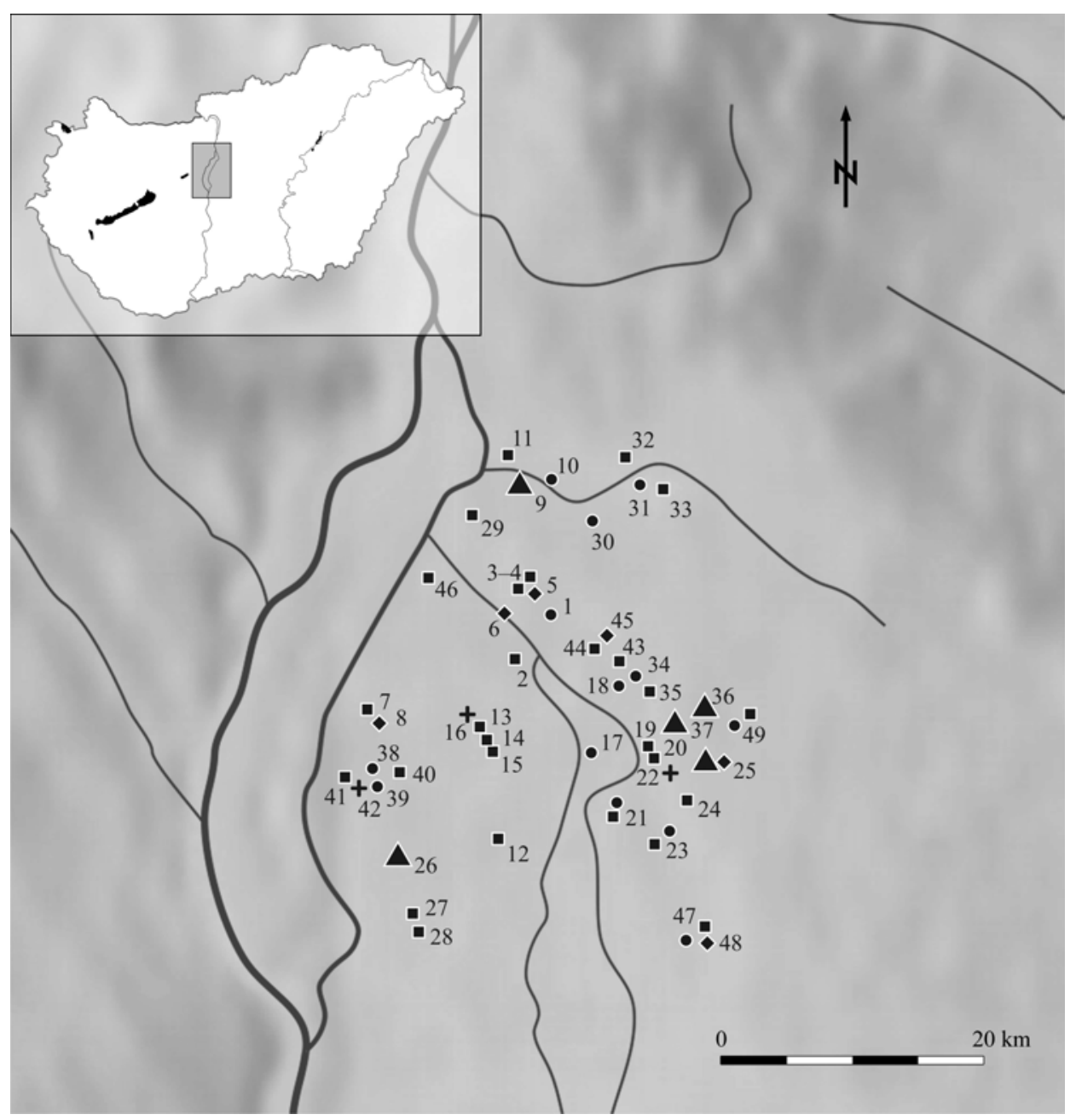

Ryc. 5. Dystrybucja stanowisk ze środkowej epoki brązu w mikroregionie Kakucs; trójkąty: telle i osady obronne; okręgi: osady otwarte; kwadraty: groby i cmentarzyska; krzyżyki: znaleziska luźne; romby: skarby brązowe (za: Kulcsár/Szeverenyi 2012)

Fig. 5. Distribution of the Middle Bronze Age within Kakucs microregion; triangles: tells and defensive settlements; circles: open settlements; squares: burials and cemeteries; crosses: stray finds; diamonds: bronze hoards (after Kulcsár/Szeverenyi 2012)

historii badań nad kulturą Vatya ${ }^{28}$ nie dysponujemy pełnymi monograficznymi opracowaniami badań archeologicznych stanowisk osadowych, które odpowiadałyby nowoczesnym standardom metodycznym. Podstawowymi problemami są braki in-

\footnotetext{
${ }^{28}$ Jaeger 2011, 6, 7 .
} 
formacji dotyczących stratygrafii, chronologii absolutnej oraz badań paleośrodowiskowych.

Zagadnienie kultury Vatya przez dekady traktowane było jako wewnętrzny problem prahistorii Węgier. Tymczasem dynamika procesów kulturowych w newralgicznym obszarze środkowego biegu Dunaju powinna należeć do podstawowych pytań europejskiej archeologii ${ }^{29}$.

Współpraca UAM z Węgierską Akademią Nauk obecnie jest kontynuowana w dwóch odsłonach. Cele projektów określone zostały komplementarnie. Mają one

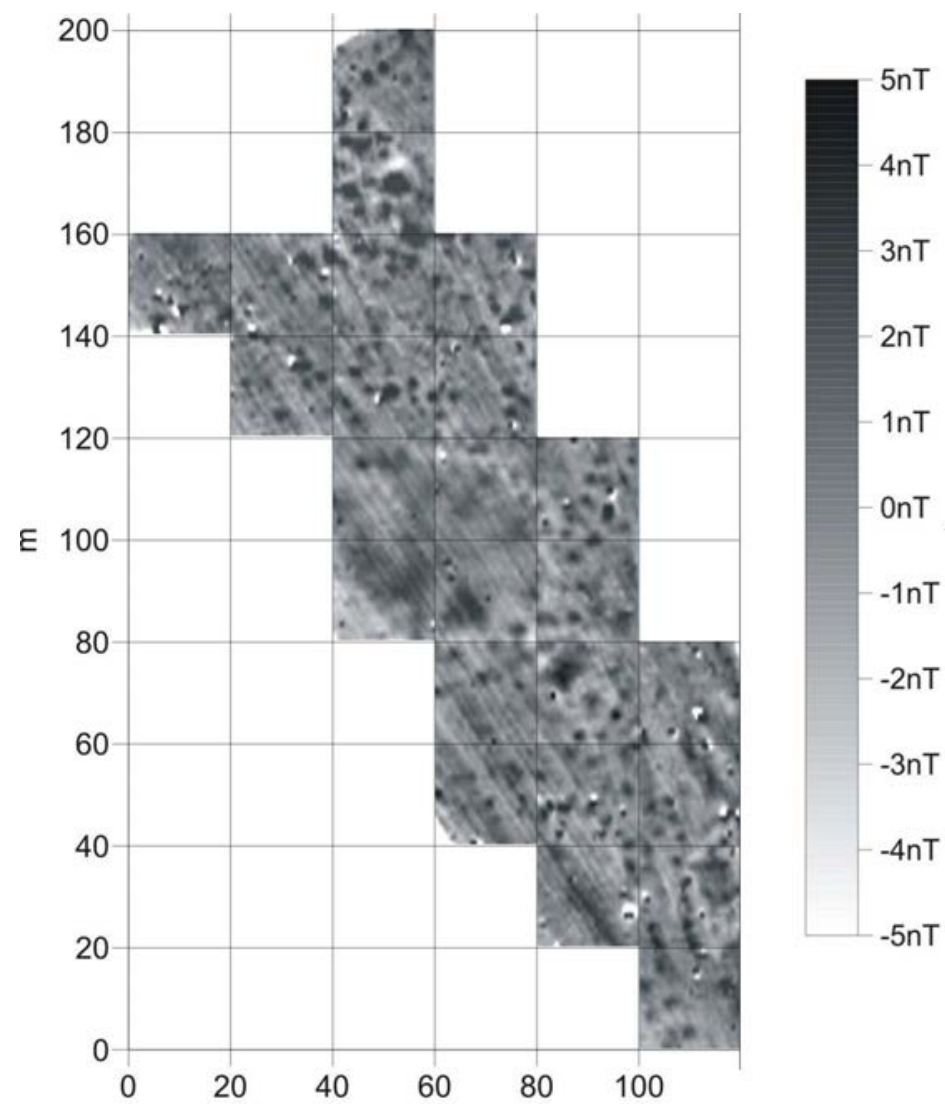

Ryc. 6. Sóskút-Kálvária. Obraz magnetyczny części osady otwartej (gradientometr Bartington Fluxgate Grad 601-1); poligony $20 \times 20 \mathrm{~m}$, siatka pomiarowa $0,25 \times 0,5 \mathrm{~m}$, wartości w przedziale $-5 \mathrm{nT} /+5 \mathrm{nT}$ (za: Earle et al 2012)

Fig. 6. Sóskút-Kálvária. Magnetic image of a part of the open settlement (gradientometer Bartington Fluxgate Grad 601-1); polygons $20 \times 20 \mathrm{~m}$, measurement grid $0.25 \times 0.5 \mathrm{~m}$, values in the range of $5 \mathrm{nT} /+5 \mathrm{nT}$ (after Earle et al 2012)

\footnotetext{
${ }^{29}$ Childe 1929; Sherratt 1993.
} 
dostarczyć danych porównawczych pochodzących z dwóch różnych mikroregionów osadniczych kultury Vatya. Pierwszy z nich realizowany jest we współpracy z archeologami węgierskimi oraz amerykańskimi. Projekt, kierowany przez profesora T. Earle'a (Northwestern University Evanston), stanowi rozwinięcie programu badawczego Százhalombatta Archaeological Expedition $\left(\mathrm{SAX}^{30}\right)$. Eponimiczne stanowisko to tell zlokalizowany $\mathrm{w}$ dolinie rzeki Benta, będący jednym $\mathrm{z}$ wielu elementów gęstej sieci osadniczej kultury Vatya. Obok osad obronnych w mikroregionie istnieją również pozostałości osad otwartych, cmentarzysk oraz znaleziska luźne ${ }^{31}$. Jednym z głównych zadań badawczych jest porównanie pozostałości osadniczych (przede wszystkim budynków mieszkalnych) na osadach obronnych i otwartych w dolinie Benta. Dotychczas podjęto pierwszy z planowanych kroków - wykonano prospekcje magnetometryczne stanowiska ufortyfikowanego w Bia oraz osady otwartej w Sóskút-Kálvária (ryc. 6), gdzie ponadto w roku 2012 przeprowadzono badania powierzchniowe i wykopaliskowe. Miejsca założenia wykopów wytypowano na podstawie korelacji wyników rozpoznania nieinwazyjnego oraz szczegółowej planigrafii zabytków związanych ze środkową epoką brązu (kultura Vatya). W trakcie wykopalisk odkryto pozostałości warstwy kulturowej oraz budynku (m.in. układy dołków posłupowych). W jednej z jam gospodarczych zarejestrowano również pochówek szkieletowy ${ }^{32}$.

Drugi projekt to najnowsza inicjatywa związana z badaniami nad problematyką osadnictwa obronnego kultury Vatya na Węgrzech. Program badawczy koncentruje się na wspomnianym mikroregionie Kakucs (ryc. 5). Obok Węgierskiej Akademii Nauk, partnerem UAM jest w tym wypadku również Christian-Albrechts Universität w Kilonii. Do tej pory w ramach realizacji projektu przeprowadzono prospekcję magnetometryczną dwóch kolejnych (po Kakucs-Turján) osad obronnych (DabasDabasi Szőlők oraz Dömsöd) oraz opracowano archiwalne wyniki badań ratowniczych osady Kakucs-Balla-domb, prezentując relatywnie długą serię nowych datowań radiowęglowych ${ }^{33}$. Główne zadania badawcze projektu realizowane są w odniesieniu do osady Kakucs-Turján. W roku 2013 rozpoczęto interdyscyplinarne badania archeologiczne stanowiska, które będą kontynuowane do roku 2015. Ich głównymi elementami są: odwierty palinologiczne, poszerzenie zbioru oznaczeń radiowęglowych, analiza archeozoologiczna oraz stabilnych izotopów węgla i azotu kości zwierzęcych, badania geochemiczne na zawartość fosforu $\mathrm{w}$ glebie, analizy z zakresu GIS oraz badania wykopaliskowe. Ostatnie ze wspomnianych zaprojektowane zostały na podstawie prospekcji magnetometrycznej (z użyciem instrumentu wielosensorowego) na obszarze najlepiej zachowanych pozostałości jednej z chat, kilku wybra-

\footnotetext{
${ }^{30}$ Poroszlai, Vicze 2000; 2005.

${ }^{31}$ Vicze, Earle, Artursson 2005.

${ }^{32}$ Earle, Kiss, Kulcsár, Szeverenyi, Czebreszuk, Jaeger, Pospieszny 2012.

${ }^{33}$ Jaeger 2011, 106-110; Jaeger, Kulcsár 2013.
} 
nych obiektów (prawdopodobnie jam o różnej funkcji) oraz tzw. bastionu. Metody przyjęte w projekcie ułatwią sformułowanie odpowiedzi na kluczowe pytania dotyczące osad obronnych kultury Vatya - zróżnicowania funkcjonalnego ich wnętrza, typu zabudowy mieszkalnej, rodzaju zajęć gospodarczych, chronologii oraz wpływu na środowisko naturalne.

\section{OSADNICTWO OBRONNE EPOKI BRĄZU W ASPEKCIE PORÓWNAWCZYM}

Archeolodzy poznańscy oprócz omówionych powyżej projektów badawczych, mających wymiar terenowy, od lat biorą czynny udział w budowaniu dyskusji naukowej wokół zagadnienia osadnictwa obronnego epoki brązu. W celu integracji środowiska specjalistów organizowane są spotkania naukowe poświęcone omawianej tematyce. W 2006 r. podczas corocznego spotkania EAA (European Association of Archaeologists) w Krakowie zorganizowana została sesja „Defensive Structures from Central Europe to the Aegean in the 3rd and 2nd millennia BC". Trzy lata później, ponownie $\mathrm{z}$ wykorzystaniem możliwości oferowanych przez coroczne spotkanie EAA, w Riva del Garda odbyła się sesja „Enclosed Space - Open Society. Contact and exchange in the context of Bronze Age Defensive Settlements in Central Europe”. Spotkania te skupiły badaczy z Polski oraz z zagranicy (m.in. Niemiec, Słowacji, Czech, Węgier, Rumunii oraz Bułgarii) i spotkały się ze znacznym zainteresowaniem uczestników. Większość zaprezentowanych podczas obu sesji referatów została opublikowana w tomach wzbogaconych o dodatkowe teksty autorów specjalizujących się w tematyce osadnictwa obronnego ${ }^{34}$. Oba tomy ukazały się w serii wydawniczej „Studia nad Pradziejami Europy Środkowej/Studien zur Archäologie in Ostmitteleuropa".

\section{PODSUMOWANIE}

Okres ostatnich lat to wyraźna intensyfikacja badań nad osadnictwem obronnym. Gromadzony konsekwentnie przez lata dorobek prezentowany jest systematycznie środowisku naukowemu podczas sesji naukowych oraz $\mathrm{w}$ formie obcojęzycznych publikacji. Liczba podejmowanych inicjatyw oraz rezultaty dotychczasowych badań w zakresie omawianej problematyki stawiają archeologię poznańską w czołówce europejskiej. Kluczem do sukcesu zdaje się strategia budowania projektów interdyscyplinarnych, o szerokim spektrum analitycznym, odpowiadających na pojawiające się trendy rozwoju tej dyscypliny. Współpraca z innymi ośrodkami naukowymi

\footnotetext{
${ }^{34}$ Czebreszuk, Kadrow, Müller 2008; Jaeger, Czebreszuk, Fischl 2012.
} 
pozwala sięgać po najlepszych specjalistów i podejmować badania nad problemami mającymi istotne znaczenie $\mathrm{w}$ kontekście najszerzej pojmowanych studiów nad europejską epoką brązu.

\section{BIBLIOGRAFIA}

Bóna I.

1992 Bronzezeitliche Tell-Kulturen in Ungarn [w:] Bronzezeit in Ungarn. Forschungen in Tell-Siedlungen an Donau und Theiss, red. W. Meier-Arendt, Frankfurt am Main, s. 9-39.

Childe V.G.

1929 The Danube in Prehistory, Oxford.

Czebreszuk J.

2011 Bursztyn w kulturze mykeńskiej. Zarys problematyki badawczej, Poznań.

Czebreszuk J., Ducke B, Müller J., Silska P.

2004 Siedlungsstrukturen und Siedlungstopographie / Struktura i topografia osady [w:] Bruszczewo. Ausgrabungen und Forschungen in einer prähistorischen Siedlungskammer Grosspolens/Badania mikroregionu z terenu Wielkopolski. Band/Tom I. Forschungsstand - Erste Ergebnisse - Das östliche Feuchtbodenareal/Stan badań Pierwsze wyniki - Wschodnia, torfowa część stanowiska, red. J. Czebreszuk, J. Müller, Poznań-Kiel-Rahden Westf., s. 71-77.

Czebreszuk J., Müller J. (red.)

2004a Bruszczewo. Ausgrabungen und Forschungen in einer prähistorischen Siedlungskammer Grosspolens / Badania mikroregionu z terenu Wielkopolski. Band/Tom I. Forschungsstand - Erste Ergebnisse - Das östliche Feuchtbodenareal/Stan badań - Pierwsze wyniki - Wschodnia, torfowa część stanowiska, Poznań-Kiel-Rahden Westf.

Czebreszuk J., Müller J.

2004b Die Lage des Fundplatzes / Położenie stanowiska [w:] Bruszczewo. Ausgrabungen und Forschungen in einer prähistorischen Siedlungskammer Grosspolens/Badania mikroregionu

z terenu Wielkopolski. Band / Tom I. Forschungsstand - Erste Ergebnisse - Das östliche Feuchtbodenareal/Stan badań - Pierwsze wyniki - Wschodnia, torfowa czesść stanowis$k a$, red. J. Czebreszuk, J. Müller, Poznań-Kiel-Rahden Westf., s. 39-43.

Czebreszuk J., Müller J., Silska P.

2004 Forschungsgeschichte und Grabungsverlauf/Historia badań stanowiska [w:] Bruszczewo. Ausgrabungen und Forschungen in einer prähistorischen Siedlungskammer Grosspolens / Badania mikroregionu z terenu Wielkopolski. Band/Tom I. Forschungsstand - Erste Ergebnisse - Das östliche Feuchtbodenareal/Stan badań - Pierwsze wyniki Wschodnia, torfowa część stanowiska, red. J. Czebreszuk, J. Müller, Poznań-KielRahden Westf., s. 13-35.

Czebreszuk J., Kadrow S., Müller J.

2008 Defensive Structures from Central Europe to the Aegean in the 3rd and 2nd millenium $B C$, Poznań-Bonn.

Czebreszuk J., Suchowska P.

2010 Die Kulturschicht am östlichen Spornrand/Warstwa kulturowa w centralnej części stanowiska [w:] Bruszczewo. Ausgrabungen und Forschungen in einer prähistorischen 
Siedlungskammer Grosspolens/Badania mikroregionu osadniczego z terenu WielkoDucke B., Müller J. polski. Band / Tom II, red. J. Müller, J. Czebreszuk, J. Kneisel, Bonn, s. 545-566.

2004 Die Geomagnetische Prospektion/Prospekcja geomagnetyczna [w:] Bruszczewo. Ausgrabungen und Forschungen in einer prähistorischen Siedlungskammer Grosspolens/ Badania mikroregionu z terenu Wielkopolski. Band / Tom I. Forschungsstand - Erste Ergebnisse - Das östliche Feuchtbodenareal/Stan badań - Pierwsze wyniki - Wschodnia, torfowa czesść stanowiska, red. J. Czebreszuk, J. Müller, Poznań-Kiel-Rahden Westf., s. 61-68.

Earle T., Kiss V., Kulcsár G., Szeverenyi V., Czebreszuk J., Jaeger M., Pospieszny Ł.

2012 Bronze Age Landscapes in the Benta Valley: Research on the Hinterland of Bronze Age Centres, http://www.hungarianarchaeology.hu/wp-content/uploads/2013/02/eng_Benta volgy_12W.pdf [dostęp: 15.06.2014]

Gediga B.

1983 Wczesnobrązowe osiedla obronne na ziemiach polskich, Archeologia Polski 28, s. 321-350.

Haas J. N., Wahlmüller N.

2010 Floren- Vegetations- und Milieuveränderungen im Zuge der bronzezeitlichen Besiedlung von Bruszczewo (Polen) und der landwirtschaftlichen Nutzung der umliegenden Gebiete / Przemiany środowiska, wegetacji i flory w ramach osadnictwa epoki brązu w Bruszczewie oraz gospodarcze użytkowanie otoczenia osady [w:] Bruszczewo. Ausgrabungen und Forschungen in einer prähistorischen Siedlungskammer Grosspolens / Badania mikroregionu z terenu Wielkopolski. Band/Tom II, red. J. Müller, J. Czebreszuk, J. Kneisel, Bonn, s. 50-81.

Heußner U., Ważny T.

2010 Synchronisation der Dendrodaten für Bruszczewo nach der ostdeutschen Kurve / Synchronizacja dat dendrochronologicznych z Bruszczewa z krzywą wschodnioniemiecką [w:] Bruszczewo. Ausgrabungen und Forschungen in einer prähistorischen Siedlungskammer Grosspolens / Badania mikroregionu z terenu Wielkopolski. Band / Tom II, red. J. Müller, J. Czebreszuk, J. Kneisel, Bonn, s. 244-247.

Horváth T., Kozák M., Pető M.

2001 The complex investigations of the stone artefacts from Vatya earthworks of Fejér county. Part I, Alba Regia 30, s. 7-20.

Jaeger M., Czebreszuk J., Müller J.

2008 Pudliszki site 5. An old hypothesis revisited [w:] Defensive Structures from Central Europe to the Aegean in the $3 r d$ and 2 nd millenium BC, red. J. Czebreszuk, S. Kadrow, J. Müller, Poznań-Bonn, s. 135-154.

Jaeger M.

2010a Transkarpackie kontakty kultury Otomani-Füzesabony [w:] Transkarpackie kontakty kulturowe w epoce kamienia, brazu i wczesnej epoce żelaza, red. J. Gancarski, Krosno, s. 313-330.

Jaeger M.

2010b Untersuchungen zum Fundplatz 5 Pudliszki und seine Zugehörigkeit zum Netz frühbronzezeitlicher befestigter Siedlungen in Großpolen / StanowiskoPudliszki 5 w ramach domniemanej sieci wczesnobrązowych osad obronnych Wielkopolski [w:] Bruszczewo. Ausgrabungen und Forschungen in einer prähistorischen Siedlungskammer Grosspolens / Badania mikroregionu osadniczego z terenu Wielkopolski. Band / Tom II, red. J. Müller, J. Czebreszuk, J. Kneisel, Bonn, s. 784-821. 
Jaeger M., Pospieszny Ł., Kulcsár G., Szeverenyi V.

2010 Wyniki badań geomegntycznych na stanowisku kultury Vatya w Kakucs, Poznań [niepublikowany raport z badań geomagnetycznych w archiwum Pracowni Archeologii Śródziemnomorskiej Epoki Brązu IP UAM].

Jaeger M

2011 Central European societies of fortified settlements in the first half of the 2nd millennium BC. A comparative study of trial areas, Poznań [maszynopis pracy doktorskiej w archiwum Instytutu Prahistorii UAM].

Jaeger M.

2012 Social Archaeology or Archaeology of Elites? Some Remarks on an Early Bronze Age Grave from Bruszczewo [w:] Beyond Elites. Alternatives to Hierarchical Systems in Modelling Social Formations, red. T. Kienlin, A. Zimmermann, [Universitätsforschungen zur Prähistorischen Archäologie 215], Bonn, s. 393-411.

Jaeger M., Czebreszuk J.

2011 Does a periphery look like that? The cultural landscape of the Unetice culture's Kościan group [w:] Landscapes and Human Development: The Contribution of European Archaeology, [Universitätsforschungen zur Prähistorischen Archäologie 191], Bonn, s. 217-235.

Jaeger M., Czebreszuk J., Fischl K. P. (red.)

2012 Enclosed Space-Open Society. Contact and Exchange in the context of Bronze Age Defensive Settlements in Central Europe, Poznań-Bonn.

Jaeger M., Kulcsár G.

2013 Kakucs-Balla-Domb. A Case Study in the Absolute and Relative Chronology of the Vatya Culture, Acta Archaeologica Hungarica 64, s. 298-320.

Kłosińska E.

1997 Starszy okres epoki brazu w dorzeczu Warty, Wrocław.

Kneisel J.

2010a Das östliche Feuchtbodenareal: Stratigrafie des Schnitt 30, Fläche 1-4/Wschodnia, wilgotna strefa stanowiska: stratygrafia wykopu 30, działki 1-4 [w:] Bruszczewo. Ausgrabungen und Forschungen in einer prähistorischen Siedlungskammer Grosspolens / Badania mikroregionu z terenu Wielkopolski. Band/Tom II, red. J. Müller, J. Czebreszuk, J. Kneisel, Bonn, s. 167-232.

2010b Eine Siedlungsbestattung der Frühbronzezeit / Pochówek na osadzie z wczesnej epoki brązu [w:] Bruszczewo. Ausgrabungen und Forschungen in einer prähistorischen Siedlungskammer Grosspolens/Badania mikroregionu z terenu Wielkopolski. Band/Tom II, red. J. Müller, J. Czebreszuk, J. Kneisel, Bonn, s. 715-720.

2010c Die Knochen- und Geweihartefakte der Schnitte 14-17/ Wyroby z kości i poroża z wykopów 14-17 [w:] Bruszczewo. Ausgrabungen und Forschungen in einer prähistorischen Siedlungskammer Grosspolens / Badania mikroregionu z terenu Wielkopolski. Band / Tom II, red. J. Müller, J. Czebreszuk, J. Kneisel, Bonn, s. 653-692.

Kneisel J., Bork H. R., Czebreszuk J., Dörfler W., Grootes P., Haas J. N., Heußner K. U., Hildebrandt-Radke I., Kroll H., Müller J., Wahlmüller N., Ważny T.

2008 Bruszczewo - Early Bronze Defensive Settlement in Wielkopolska. Metallurgy, peat zone finds and change in the environment [w:] Defensive Structures from Central Europe to the Aegean in the $3 r d$ and 2 nd millenium BC, red. J. Czebreszuk, S. Kadrow, J. Müller, Poznań-Bonn, s. 155-170.

Kneisel J., Kroll H.

2010 Die Holzanalysen aus dem östlichen Feuchtbodenareal / Analizy drewna z części torfowej stanowiska [w:] Bruszczewo. Ausgrabungen und Forschungen in einer prähistori- 
schen Siedlungskammer Grosspolens / Badania mikroregionu z terenu Wielkopolski. Band / Tom II, red. J. Müller, J. Czebreszuk, J. Kneisel, Bonn, s. 567-652.

Kovács T.

1982 Befestigungsanlage um die Mitte des 2. Jahrtausends v.u.Z. in Mittelungarn [w:] Beiträge zum bronzezeitlichen Burgenbau in Mitteleuropa, red. B. Chropovský, J. Herrmann, Berlin-Nitra, s. 279-291.

Kulcsár G., Szeverenyi V.

2012 Middle Bronze Age Settlement and Society in Central Hungary [w:] Enclosed SpaceOpen Society. Contact and Exchange in the context of Bronze Age Defensive Settlements in Central Europe, red. M. Jaeger, J. Czebreszuk, K.P. Fischl, Poznań-Bonn, s. 287-352.

Makowiecki D.

2004 Archäozoologische Untersuchungen zu den frühbronzezeitlichen Tierknochen aus ausgewählten Befunden/Badania archeozoologiczne szczątków kostnych z wybranych części osady [w:] Bruszczewo. Ausgrabungen und Forschungen in einer prähistorischen Siedlungskammer Grosspolens / Badania mikroregionu z terenu Wielkopolski. Band / Tom I. Forschungsstand - Erste Ergebnisse - Das östliche Feuchtbodenareal/Stan badań - Pierwsze wyniki - Wschodnia, torfowa część stanowiska, red. J. Czebreszuk, J. Müller, Poznań-Kiel-Rahden Westf., s. 281-290.

Makowiecki D., Drejer A.

2010 Analiza chronologiczna i przestrzenna zwierzęcych szczątków kostnych wydobytych w Bruszczewie w latach 1964-1968 / Chronologische und chorologische Analyse der in Bruszczewo gefundenen Knochenreste aus den Jahren 1964-1968 [w:] Bruszczewo. Ausgrabungen und Forschungen in einer prähistorischen Siedlungskammer Grosspolens / Badania mikroregionu osadniczego z terenu Wielkopolski. Band/Tom II, red. J. Müller, J. Czebreszuk, J. Kneisel, Bonn, s. 288-315.

Marciniak A.

2010 Taphonomie der Knochenfunde aus Bruszczewo - ein Vorbericht / Tafonomia materiałów kostnych z Bruszczewa. Wprowadzenie [w:] Bruszczewo. Ausgrabungen und Forschungen in einer prähistorischen Siedlungskammer Grosspolens / Badania mikroregionu z terenu Wielkopolski. Band / Tom II, red. J. Müller, J. Czebreszuk, J. Kneisel, Bonn, s. 316-343.

Meier-Arendt W. (red.)

1991 Bronzezeit in Ungarn. Forschungen in Tell-Siedlungen an Donau und Theiss, Frankfurt am Main.

Müller J., Czebreszuk J., Kneisel J. (red.)

2010 Bruszczewo. Ausgrabungen und Forschungen in einer prähistorischen Siedlungskammer Grosspolens / Badania mikroregionu osadniczego z terenu Wielkopolski. Band / Tom II, Bonn.

Müller J.

2004 Die östlichen Feuchtbodenareale: Stratigraphien und Architektur / Strefa torfowa stanowiska: stratygrafia i architektura [w:] Bruszczewo. Ausgrabungen und Forschungen in einer prähistorischen Siedlungskammer Grosspolens / Badania mikroregionu z terenu Wielkopolski. Band / Tom I. Forschungsstand - Erste Ergebnisse - Das östliche Feuchtbodenareal / Stan badań - Pierwsze wyniki - Wschodnia, torfowa część stanowiska, red. J. Czebreszuk, J. Müller, Poznań-Kiel-Rahden Westf., s. 99-134.

Müllern J., Czebreszuk J.

2003 Bruszczewo - eine frühbronzezeitliche Siedlung mit Feuchtbodenerhaltung in Großpolen. Vorbericht zu den Ausgrabungen 1999-2001, Germania 81, s. 443-480. 
Németi J., Molnár Z.

2012 Bronzkori hatalmi központok északnyugat-erdélyben: a Nagykároly-Bobáld-tell, Szeged.

Poroszlai I., Vicze M. (red.)

2000 Százhalombatta Archaeological Expedition Report I, Százhalombatta.

Poroszlai I., Vicze M. (red.)

2005 Százhalombatta Archaeological Expedition Report II, Százhalombatta.

Rassmann K.

2004 Die Bemerkungen zu den chemischen Analysen von Kupferartefakten aus der Siedlung von Bruszczewo / Uwagi na temat analiz chemicznych wyrobów miedzianych z Bruszczewa [w:] Bruszczewo. Ausgrabungen und Forschungen in einer prähistorischen Siedlungskammer Grosspolens / Badania mikroregionu z terenu Wielkopolski. Band / Tom I. Forschungsstand - Erste Ergebnisse - Das östliche Feuchtbodenareal/Stan badań Pierwsze wyniki - Wschodnia, torfowa część stanowiska, red. J. Czebreszuk, J. Müller, Poznań-Kiel-Rahden Westf., s. 257-262.

2010 Neue chemische Analysen von Kupferartefakten aus der Siedlung von Bruszczewo/Nowe analizy chemiczne wyrobów miedzianych z osady w Bruszczewie [w:] Bruszczewo. Ausgrabungen und Forschungen in einer prähistorischen Siedlungskammer Grosspolens / Badania mikroregionu z terenu Wielkopolski. Band / Tom II, red. J. Müller, J. Czebreszuk, J. Kneisel, Bonn, s. 702-712.

Sherratt A.

1993 What would a Bronze Age World System Look like?, European Journal of Archaeology 1 (2), s. 1-58.

Stróżyk M.

2011 Architektura wczesnej epoki brązu. Próba wirtualnej rekonstrukcji osady w Bruszczewie, Poznań [maszynopis pracy magisterskiej, Biblioteka Instytutu Prahistorii UAM].

Vicze M., Earle T., Artursson M.

2005 Bronze Age site gazetteer: Benta Valley, Hungary [w:] Százhalombatta Archaeological Expedition Report II, red. I. Poroszlai, M. Vicze, Százhalombatta, s. 237-250.

\section{INVESTIGATIONS OF BRONZE AGE FORTIFIED SETTLEMENTS BY ARCHAEOLOGISTS FROM POZNAŃ}

\section{S u m m a r y}

Defensive settlement is one of the most important elements of the study of the European Bronze Age. Numerous settlements surrounded with artificial defensive structures pose a serious organizational and financial challenge for archaeologists. The level of complexity and richness of data offered by the defensive settlements (artefacts and ecofacts) requires a long-term archaeological and interdisciplinary study.

The article presents the experience of Poznan researchers in the field of building and realising research projects within international teams, involving experts from various fields of science. Last two decades have been the time of apparent intensification of research on defensive settlement, both in Poland and abroad (Hungary).

Translated by Lucyna Leśniak 